\title{
Level Of Labor Pain On First Stage Of Normal Labor \\ In Dr.H. Moch Ansari Saleh Banjarmasin Hospital
}

\author{
Lisda Handayani ${ }^{1 *}$ \\ ${ }^{1}$ Academy of Midwifery Sari Mulia Banjarmasin Indonesia \\ *lisda_handayani@akbidsarimulia.ac.id \\ Desilestia Dwi Salmarini ${ }^{1}$ \\ ${ }^{1}$ Academy of Midwifery Sari Mulia Banjarmasin Indonesia \\ Desilestia_dwi_salmarini@akbidsarimulia.ac.id \\ Nurlia Rezekika ${ }^{1}$ \\ ${ }^{1}$ Academy of Midwifery Sari Mulia Banjarmasin Indonesia \\ nurliarezekika@gmail.com
}

\begin{abstract}
Objective: To described level of labor pain on first stage of Normal labor in Dr. H. Moch Ansari Saleh Banjarmasin Hospital.

Methods: This research used descriptive method. Population on the research are all of normal labor women and sample used 30 people who normal labor with accidental sampling techniques. Data collecting by observation on the labor used check list.

Results: result showed level of labor pain on first stage of normal labor are moderate labor pain 15 paople $(50 \%)$ it happened when the delatation 4-6 cM, severe pain 12 people $(40 \%)$ when the dilatation $4-8 \mathrm{~cm}$ and very severe pain 3 people (10\%) when the delataion 4-9 $\mathrm{cM}$.

Conclusion: when the dilatation added, the labor pain would be increased.
\end{abstract}

Keywords: first stage, labor pain, normal labor, pain.

\section{INTRODUCTION}

Maternal Mortality Rate (MMR) is

one of the Indicator to view the health status of women. Demographic Health Survey Indonesia in 2012 showed MMR achieved 359 per 100.000 childbirth. Indonesia committed to reducing MMR to 108 per 100.000 childbirth in 2015 , according to the Millennium Development Goals. Causes of maternal death in Indonesia are still dominated by bleeding (28\%), hypertension in pregnancy (24\%), infection (11\%), prolonged labor (5\%) and miscarriages $(5 \%)$ [1].

The labor is identical to the pain that occurs when the muscles of the uterus as an effort to open the cervix and push the baby's head towards the pelvis. Pain in the first stage of labor is a physiological process that is caused by the dilation of the cervix, hypoxia uterine muscle, ischemia corpus uteri and stretching the lower uterine segment that makes the pain increase [2].

Labor pain can also make hyperventilation that increased oxygen 
demand, rise in blood pressure, and reduces the motility bowel and bladder. This situation will stimulate an increase in catecholamine which may cause the strength of uterine contractions resulting in inertia uterine. If the labor pain can not overcome will make prolonged labor. Prolonged labor contributed the MMR by $5 \%$ [3].

Analysis by Afifah shows labor pain in primigravida mostly experiencing severe pain, the pain was $26,7 \%$ and $6.7 \%$ severe pain. Labor pain of multigravida mother showed mostly mild pain as much as $60 \%$, moderate pain as much as $40 \%$. So there is a difference in the level of the first stage of labor pain on normal birth mothers primigravida and multigravida in Nur Hikmah Kuwaron village Gubug Grobogan Maternity Hospital (p-value $=<0,05)$ [4]

Based on data obtained from Dr.H.Moch Ansari Saleh Banjarmasin hospital was found that during the period January to September 2014 of normal labor as many as 901 mother. The researcher did by using direct observation method during May 2016 to 30 mother of normal labor .

The purpose of this study was to describe Level of Labor Pain on the first stage of Normal labor in Dr. H. Moch Ansari Saleh Banjarmasin Hospital.

\section{METHODS}

The population in this study were all normal maternity mothers in Dr.H. Moch Ansari Saleh Banjarmasin Hospital in May
2016 as many as 110 people. The sampling technique in this research is accidental sampling with 30 samples.

Types of Research is descriptive study where did on 20 untill 28 of May 2016 in delivery room dr. H. Moch Ansari Saleh Banjarmasin hospital with the variables is labor pain on first stage of normal labor.

Data collected by observation with a check list. The researcher observed the labor women respondents on the first stage. Analyzed in this research by directly observed the level of labor pain of the first stage of normal labor. The level of pain measured with a numerical scale.

\section{RESULTS}

1. Level of Labor Pain on first stage at dr. H. Moch Ansari Saleh Banjarmasin Hospital.

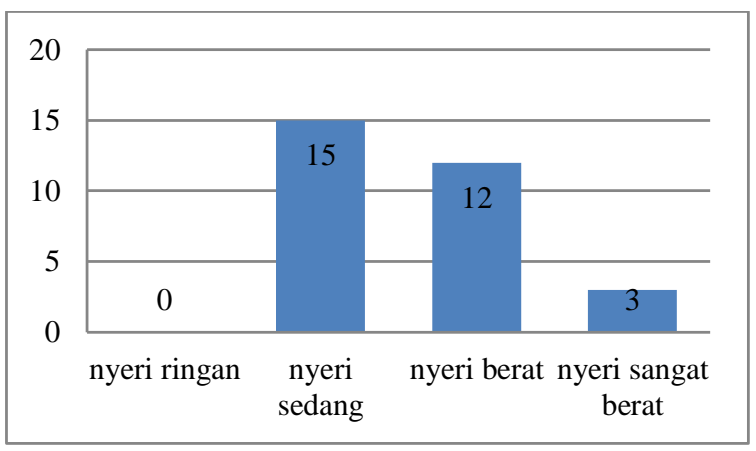

Picture 1 Frequency Distribution of Level Pain on Normal Labor at Active Phase at Dr.H.Moch Ansari Saleh Banjarmasin Hospital

Based on picture 1 can be seen that the level pain overview of the active phase of the first stage of labor in Dr.H.Moch 
Ansari Saleh Banjarmasin hospital found respondents as many as 30 people, were grouped based on the level of pain are mild pain from $0(0 \%)$, moderate pain as many as 15 people (50\%), severe pain as many as 12 people $(40 \%)$ and very heavy pain 3 people $(10 \%)$.

2. Characteristics Level of Labor Pain

a. Based on dilatation

Table 1 Distribution Frequency Rate of

First Stage of Labor Pain Based On dilatation in hospital Dr.H.Moch Ansari Saleh Banjarmasin Hospital

\begin{tabular}{|c|c|c|c|c|c|c|c|c|c|c|}
\hline \multirow[t]{3}{*}{ Parity } & \multicolumn{8}{|c|}{ Pain Rate } & \multicolumn{2}{|c|}{ amount } \\
\hline & \multicolumn{2}{|c|}{ Light } & \multicolumn{2}{|c|}{ Medium } & \multicolumn{2}{|c|}{ Weight } & \multicolumn{2}{|c|}{$\begin{array}{l}\text { Very } \\
\text { heavy }\end{array}$} & & \\
\hline & $\mathrm{F}$ & $\%$ & $\mathrm{~F}$ & $\%$ & $\mathrm{~F}$ & $\%$ & $\mathrm{~F}$ & $\%$ & $\mathrm{~F}$ & $\%$ \\
\hline Nulipara & 0 & 0 & 6 & 75 & 1 & 12.5 & 1 & 12.5 & 8 & 100 \\
\hline Primipara & 0 & 0 & 6 & 43 & 7 & 50 & 1 & 7 & 14 & 100 \\
\hline Multipara & 0 & 0 & 3 & 50 & 3 & 50 & 0 & 0 & 6 & 100 \\
\hline Grandemultipara & 0 & 0 & 0 & 0 & 1 & 50 & 1 & 50 & 2 & 100 \\
\hline amount & & 0 & 15 & 50 & 12 & 40 & 3 & 10 & 30 & 100 \\
\hline
\end{tabular}

Based on Table 1 it can be seen that out of 30 respondents grouped by dilatation with the level of pain there is not found respondents with mild pain, moderate pain ranges dilatation from $4-6 \mathrm{~cm}$ is $90 \%$, severe pain around dilatation from $4-8 \mathrm{~cm}$ is $55 \%$, very severe pain ranges dilatation $6-9 \mathrm{~cm}$ is $100 \%$.

\section{b. By Age}

Table 2 Distribution Frequency of First Stage of Labor Pain Based On Age in Dr.H.Moch Ansari Saleh Banjarmasin Hospital

\begin{tabular}{|c|c|c|c|c|c|c|c|c|c|c|}
\hline \multicolumn{3}{|c|}{$\begin{array}{c}\text { Age } \\
\text { category }\end{array}$} & \multicolumn{6}{|c|}{ Pain Rate } & \multicolumn{2}{|c|}{ amount } \\
\hline & \multicolumn{2}{|l|}{ Light } & \multicolumn{2}{|c|}{ Medium } & \multicolumn{2}{|c|}{ Weight } & \multicolumn{2}{|c|}{$\begin{array}{l}\text { Very } \\
\text { heavy }\end{array}$} & & \\
\hline & $\mathrm{F}$ & $\%$ & F & $\%$ & $\mathrm{~F}$ & $\%$ & $\mathrm{~F}$ & $\%$ & $\mathrm{~F}$ & $\%$ \\
\hline$<20$ & 0 & 0 & 1 & 100 & 0 & 0 & 0 & 0 & 1 & 100 \\
\hline $20-35$ & 0 & 0 & 12 & 50 & 10 & 42 & 2 & 8 & 25 & 100 \\
\hline$>35$ & 0 & 0 & 2 & 40 & 2 & 40 & 1 & 20 & 5 & 100 \\
\hline amount & 0 & 0 & 15 & 50 & 12 & 40 & 3 & 10 & 30 & 100 \\
\hline
\end{tabular}

Based on Table 2 from 30 respondents grouped according to age and level of pain there are $<20$ years old gained moderate pain as much as 1 person, 20-35 years old showed moderate pain as many as 12 people, and > 35 years old showed moderate pain and very heavy as much as 2 people.

c. Based on Parity

Table 3 Frequency Distribution Stage of Labor Pain on First Stage at Active Phase Based on Parity in Dr.H.Moch Ansari Saleh Banjarmasin Hospital

\begin{tabular}{lllllllllll}
\hline \multirow{2}{*}{ Opening } & \multicolumn{9}{c}{ Pain Rate } & \multicolumn{5}{c}{ amount } \\
\cline { 2 - 8 } & Light & \multicolumn{1}{c}{ Medium } & \multicolumn{1}{c}{ Weight } & \multicolumn{2}{c}{$\begin{array}{l}\text { Very } \\
\text { weight }\end{array}$} \\
\cline { 2 - 9 } & F & $\%$ & F & $\%$ & F & $\%$ & F & $\%$ & F & $\%$ \\
\hline $4 \mathrm{~cm}$ & 0 & 0 & 9 & 90 & 1 & 10 & 0 & 0 & 10 & 100 \\
$5 \mathrm{~cm}$ & 0 & 0 & 5 & 45 & 6 & 55 & 0 & 0 & 11 & 100 \\
$6 \mathrm{~cm}$ & 0 & 0 & 1 & 25 & 2 & 50 & 1 & 25 & 4 & 100 \\
$7 \mathrm{~cm}$ & 0 & 0 & 0 & 0 & 1 & 50 & 1 & 50 & 2 & 100 \\
$8 \mathrm{~cm}$ & 0 & 0 & 0 & 0 & 1 & 50 & 1 & 50 & 2 & 100 \\
$9 \mathrm{~cm}$ & 0 & 0 & 0 & 0 & 0 & 0 & 1 & 100 & 1 & 100 \\
\hline amount & 0 & 0 & 15 & 50 & 11 & 37 & 4 & 13 & 30 & 100 \\
\hline
\end{tabular}

Based on Table 3 can be seen from a total of 30 respondents classified based on the level of pain of respondents with the results, in nulliparous of 8 people who experience 
moderate pain as much as 6 people, severe pain as much as one person and severe pain as much as one person. In primiparous of 14 people who experienced moderate pain as much as 6 people, severe pain as many as 7 people and very heavy pain as much as 1 person. In multiparous of 6 people who experienced moderate pain as many as 3 people and severe pain as much as 3 people. In the grandemultiparous of 2 people who experienced severe pain as much as 1 person and very heavy pain as much as 1 person.

\section{DISCUSSION}

Overview of Research Results Stage of Labor Pain on first stage on Active Phase in Dr.H.Moch Ansari Saleh Banjarmasin hospital obtained 30 people are grouped based on the level of pain of moderate pain known to as many as 15 people (50\%) and very severe pain only 3 people (10\%). Labor pain is a response where individuals who participate in the delivery process because of the physiological changes passage and uterine [5]. Pain can occur because of uterine contraction regulary with intensity is getting stronger and increasing shorter intervals, accompanied by a dilatationof cervix affected the intensity of labor pain and became one of the factors that affect of labor [6].

Based on research Woo [7] with severe labor pain have an increased risk of cesarean delivery was significantly higher than in patients with moderate labor pain $(\mathrm{P}=0.006)$. Labor pain can be controlled by breathing relaxation techniques to minimize sympathetic activity in the autonomic nervous system. The technique can reduce the sensation of pain and control the intensity of the mother's reaction to pain [10].

Based on the research note that the larger the dilatation the degree of pain will more, can be seen from Table 2 from $4 \mathrm{~cm}$ dilatation are $90 \%$ had moderate pain, $8 \mathrm{~cm}$ dilatation are $50 \%$ experiencing severe pain and $50 \%$ had pain very severe while $9 \mathrm{~cm}$ dilatation are $100 \%$ experience very severe pain. Based Mander [8] labor pain is not constant, but intermittent. In the first stage, pain due to thinning and cervical dilatation. At the dilatation on $0-3 \mathrm{~cm}$, pain is felt sick and uncomfortable. The second stage pain arising from a decrease in fetal head pressing and interesting parts in the pelvic area, where the opening of 4-7 cm somewhat stabbing pain, more severe pain of $7-10 \mathrm{~cm}$, shortly rafter and stiff.

This is consistent with study showed that the higher the dilatation then an increase also of the pain and the contraction in maternal first stage on active phase conducted in 3 phases during the first stage where the peak occurrence of pain and contractions in the mother at the dilatation of $10 \mathrm{~cm} \mathrm{[6].}$

The results of Chi-square statistic based on the Q-test and I2 indicate heterogeneity among studies in the latent phase $(\mathrm{Q}=63,52$, $\mathrm{P}<0.001$ and $\mathrm{I} 2=87.4 \%)$, the active phase $(\mathrm{Q}$ $=26.42, \mathrm{P}<0.001$, and $\mathrm{I} 2=77.3 \%$ ), and transition phases $(\mathrm{Q}=104.84, \mathrm{P}$ values 
$<0.001$, and $\mathrm{I} 2=95.2 \%)$. The results showed that massage therapy reduces pain in labor in the latent phase (SMD $=-1,23,95 \%$ CI: -1.73 to -0.74$)$, the active phase $(\mathrm{SMD}=-1.59,95 \%$ CI: $-2,06$ to -1.12 ), and phase transitions $(\mathrm{SMD}=-1.90,95 \% \mathrm{CI}:-3.09$ to -0.71$)$. This study provides valid evidence for the effects of massage therapy in Iran to relieve labor pain. Therefore, the use of massage therapy can be recommended in primiparous women [11]

Evidance based in obstetrics showed the continued support of a midwife can influence first stage of labor [12]. Based on a review of position and mobility during labor it concluded that walking position in the first stage reduces the duration of labor, the risk of caesarean birth, the need for epidural and maternal intervention. Women should be encouraged to take whatever position they find most comfortable in the first stage of labor [13]. In addition ongoing support is most effective when given by women who is not part of the hospital staff or the women's social network [14].

Labor pain in the study if seen by age of the mothers, more severe level pain, it can be seen from Table 3 Maternal age $<20$ years of $100 \%$ experience moderate pain, while in women with age 20-35 years and > 35 years experienced $40-42 \%$ severe pain and $8-20 \%$ experienced very severe pain. This is consistent with studies that the age of the mother were very old complained of pain in labor is high. Pregnant women with age $<20$ years or> 35 years of a child-bearing age high risk as possible abnormalities or disorders in the fetus, causing anxiety to the level of pain is more. In another study mentioned that there was a significant association between maternal age with labor pain on the first stage of the active phase, where the average pain felt by the mother at the age of high risk ( $<20$ or $>35$ years) is higher than the age of the mother at low risk ( 20-35 years) [6].

Labor pain seen from maternal parity in mind that more and more parity, the more severe levels of $\mathrm{n}$ yeri where nulliparous mothers $75 \%$ had moderate pain, seda ngkan maternal Grandemultipara 50\% experiencing severe pain. Researched by Tarsikah [9] mentioned that primiparous experienced greater pain in early labor, while multipara increased levels of pain after delivery with a rapid decline in the second stage of labor. This means that there is a difference between previous research with the results of this study, this occurs because the measured pain primiparous mother when the dilatation between 4-6 cm whereas in grand multiparous measured when the dilatation between 8-9 $\mathrm{cm}$. cervical dilatation differences affect the level of pain, that happened because regular presence with the intensity of uterine contraction increasingly powerful and increasingly shorter intervals, accompanied by cervix dilatation, affecting the intensity of labor pain and became one of the factors that affect labor. Seen from the results of the 
study, Nulliparaous $75 \%$ had moderate pain with an average of 4-6 cm dilatation on primiparous women is $50 \%$ had severe pain with average of 4-7 cm dilatation, multipara $50 \%$ had moderate pain and $50 \%$ had severe pain with average dilatation $5 \mathrm{~cm}$ and on grand multiparous $50 \%$ experienced severe pain and $50 \%$ experienced very severe pain with an average dilatation of $8-9 \mathrm{~cm}$. Grandemultiparous group into a group so that pain is more severe than the other groups [4]. It is described in theory that the more often and the longer his cervical dilatation is getting bigger and stronger pain intensity [8]. In primigravida, the process of cervical leveling occurs first compared to the opening, so the process is longer than multigravida. This process will result in fatigue that can affect the increase in the perception of pain [9].

\section{CONCLUSION}

Labor pain in the first stage of normal labor in Dr.H.Moch Ansari Saleh Banjarmasin hospital obtained based on the level of pain, the pain was $15(50 \%)$ in women with $4-6 \mathrm{~cm}$ of dilatation cervix, severe pain in $12(40 \%)$ of 4- $8 \mathrm{~cm}$ dilatation cervix and very severe pain $3(10 \%)$ at $6-9 \mathrm{~cm}$ dilatation cervix. This showed when the dilatation added, the labor pain will increase.

\section{REFERENCES}

[1]. Kementerian Kesehatan RI. Profil Kesehatan Indonesia 2010. (internet). tersedia dari http://www.depkes.go.id. 2011

[2]. Sumarah. Perawatan Ibu Bersalin: Asuhan Kebidanan Pada Ibu Bersalin.Yogyakarta: Mitra Cendikia Press. 2009

[3]. Andarmoyo. S., Suhartati. Persalinan Tanpa Nyeri Berlebihan. Yogyakarta: Ar-Ruzz Media. 2013

[4]. Afifah, Durotun; dkk. Perbedaan Tingkat Nyeri Persalinan Kala I Pada Ibu Bersalin Normal Primigravida Dan Multigravida Di Rb Nur Hikmah Desa. 2011

[5]. Judha, Mohamad. Teori Pengukuran Nyeri Dan Nyeri Persalinan. Yogyakarta: Nuha Medika. 2012

[6]. Magfuroh, Annisa. Faktor-faktor yang berhubungan dengan nyeri persalinan kala I fase aktif diruang bersalin RSU Kabupaten repository.uinjkt.ac.id. 2015

Tangerang.

[7]. Woo, Kim, Lee, Baik, Kim, Chung et all. The degree of labor pain at the time of epidural analgesia in nulliparous women influences the obstetric outcome Korean Journal Anesthesiology. 2015 Jun;68(3):249-253.

[8]. Mander, Rosemary. Nyeri Persalinan. Jakarta: EGC. 2003

[9]. Tarskiah dkk. Penurunan Nyeri Persalinan Primigravida Kala I Fase Aktif Pascapenghirupan Aromaterapi Lavender. Poltekkes Kemenkes; Malang. 2012

[10]. Herawati, R. Evaluasi Teknik relaksasi yang Efektif dalam Penatalaksanaan Nyeri Kala I Terhadap Keberhasilan Persalinan Normal. Jurnal Maternity and Neonatal. 2016. Volume 2 No 2 page 102-116

[11]. Ranjbaran, Khorsandi, Matourypour, Shamsi. Effect of Massage Therapy on Labor Pain Reduction in Primiparous Women: A Systematic Review and Meta-analysis of Randomized Controlled Clinical Trials in Iran. 
PubMed. Iran J Nurs Midwifery Res. 2017. Jul-Aug;22(4):257-261

[12]. Irvani, Jonghorbani, Zarean, Bahrami. An overview of Systematic Reviews of Normal Labor adn Delivery Management. Iranian Journal of Nursing and Midwifery Research. 2015. Volume 20(3). 293-303

[13]. Lawrence A, Lewis L, Hofmeyr GJ, Dowswell T, Styles C. PubMed. Maternal positions and mobility during first stage labour. Cochrane Database Syst Rev. 2013;(10):CD003934.

[14]. Hodnett ED, Gates S, Hofmeyr GJ, Sakala C. PubMed. Continuous support for women during childbirth. Cochrane Database Syst Rev. 2013;(7):CD003766 